\title{
Follow-Up Investigations of Tau Protein and S-100B Levels in Cerebrospinal Fluid of Patients with Creutzfeldt-Jakob Disease
}

\author{
Lukas Cepek $^{a}$ Petra Steinacker ${ }^{a}$ Brit Mollenhauer ${ }^{a}$ Birgitt Wiese $^{b}$ \\ Barbara Ciesielczyk $^{\mathrm{a}}$ Mirko Bibl $^{\mathrm{c}}$ Jens Wiltfang ${ }^{\mathrm{e}}$ Inga Zerr ${ }^{\mathrm{a}}$ \\ Walter Schulz-Schaeffer ${ }^{d}$ Hans A. Kretzschmar ${ }^{f}$ Sigrid Poser $^{a}$ Markus Otto ${ }^{a}$ \\ Departments of a Neurology, ${ }^{b}$ Medical Informatics, ${ }^{c}$ Psychiatry, ${ }^{d}$ Neuropathology, University of Göttingen, \\ Göttingen; ${ }^{e}$ Psychiatry, University of Nuremberg/Erlangen, Nuremberg/Erlangen, and ${ }^{f}$ Neuropathology, \\ University of Munich, Munich, Germany
}

\section{Key Words}

Creutzfeldt-Jakob disease $\cdot$ S-100B $\cdot$ Tau protein

\begin{abstract}
Background: S-100B and tau protein have a high differential diagnostic potential for the diagnosis of CreutzfeldtJakob disease (CJD). So far there has been only limited information available about the dynamics of these parameters in the cerebrospinal fluid (CSF). However, there is a special interest in finding biochemical markers to monitor disease progression for differential diagnosis and treatment. Patients and Methods: We analyzed CSF of 45 patients with CJD and of 45 patients with other neurological diseases for tau protein and S-100B in a follow-up setting. All diagnoses of CJD were later neuropathologically verified. A ratio between tau protein differences and the time between lumbar puncture was calculated. The same was done for S-100B. Results: Tau protein levels of 34 cases were above the cut-off level for CJD $(>1,300 \mathrm{pg} / \mathrm{ml})$ in the first CSF sample. In 7 of $11 \mathrm{pa}-$ tients with lower tau levels in the first CSF sample, tau levels rose. The above-mentioned ratio was significantly higher in the CJD group than in the group with other neurological diseases. Similar results were obtained for
\end{abstract}

S-100B. Conclusion: We conclude that follow-up investigations and calculation of ratios is a useful tool in the differential diagnosis of CJD. Variations in this pattern were observed in single cases.

Copyright $(2005$ S. Karger AG, Basel

\section{Introduction}

Up to now, the intra vitam diagnosis of CreutzfeldtJakob disease (CJD) has been made according to clinical and electroencephalographic criteria [1]. The clinical diagnosis of CJD can be supported by biochemical analysis of cerebrospinal fluid (CSF) for tau protein [2-5], S-100B $[6,7]$ or $14-3-3$ protein [8-10]. So far, only the 14-3-3 immunoblot is included in the diagnostic criteria [11], despite the fact that the other surrogate markers also have a high differential diagnostic potential and that the diagnostic accuracy of 14-3-3 proteins was challenged recently $[6,12-15]$. The final diagnosis of CJD can only be made neuropathologically by demonstrating the pathological isoform of the prion protein $\left(\mathrm{PrP}^{\mathrm{Sc}}\right)$ [16]. Routine detection of $\mathrm{PrP}^{\mathrm{Sc}}$ outside the brain for an early in vivo diagnosis of sporadic CJD has yet to become established. First attempts to detect PrP aggregates were made using fluo-

\section{KARGER \\ Fax +4161306 1234 E-Mailkarger@karger.ch} www.karger.com
(C) 2005 S. Karger AG, Basel $1420-8008 / 05 / 0196-0376 \$ 22.00 / 0$ www.karger.com/dem
Markus Otto, MD

Department of Neurology, University of Göttingen

Robert-Koch Strasse 40

DE-37070 Göttingen (Germany)

Tel. +49 55139 8404, Fax +49 55139 14449, E-Mail motto@gwdg.de 
Table 1. Patient characteristics

\begin{tabular}{llll}
\hline Diagnosis & Male/female & \multicolumn{2}{l}{ Age, years } \\
\cline { 3 - 4 } & & median & range \\
\hline CJD & & 61 & $19-77$ \\
Sporadic & $16 / 23(39)$ & 62 & $57-77$ \\
Genetic & $3 / 3(6)$ & 60 & $27-80$ \\
OND & $22 / 23(4)$ & & \\
\hline
\end{tabular}

Neuropathologically confirmed cases are shown in parentheses.

rescence-correlated spectroscopy [17]. The situation for patients with new variant CJD ( $\mathrm{VCJD})$ is different as a pathological isoform also was detected in the tonsils of these patients [18].

Although CJD is rare, it is often considered in the differential diagnosis, especially at the beginning of a dementing process. The measurement of tau protein and amyloid beta peptides in CSF has gained wide acceptance in the differential diagnosis of dementias [19,20]. But up to now there is only limited information available on follow-up levels of these markers, especially in patients with a differential diagnosis of CJD. Such information should help to improve diagnostic accuracy for unclear cases. On the other hand, follow-up investigations of biological markers might be an alternative tool to monitor effects of upcoming therapeutic approaches for CJD or other neurodegenerative diseases like Alzheimer's disease (AD) $[21,22]$.

In our study we measured the levels of tau protein and S-100B as for these markers quantitative assays with acceptable variation coefficients are available. In previous studies, optimal cut-off levels for tau protein and S-100B for the diagnosis of CJD were already obtained [2, 4, 6, 7].

\section{Patients and Methods}

We analyzed CSF of 90 patients with a differential diagnosis of CJD. Forty-five of these patients were later neuropathologically confirmed as CJD cases. In the remaining 45 patients, other neurological diseases (OND) were diagnosed. Tau protein was measured repetitively in CSF of 78 patients and S-100B protein was measured in CSF of 51 patients. According to the clinical criteria, all suspected cases of CJD were classified as 'probable', 'possible' or 'other' cases [11,23, 24]. Samples from these patients were obtained from the CSF bank of the German CJD counseling laboratory.

Tau Protein and S-100 Levels in

Cerebrospinal Fluid of CJD Patients
The diagnoses in the OND group were as follows: 8 patients with $\mathrm{AD}, 4$ patients with corticobasal degeneration (CBD), 4 patients with vascular dementia (VD), 3 hepatic encephalopathies, 2 with neoplastic diseases of the brain, 2 patients with frontotemporal dementia (FTD), 2 with depression, 2 with epilepsy, 1 patient with Lewy body dementia (LBD), 1 patients with motor neuron disease, 1 with progressive subcortical gliosis (Neumann-Cohns disease), 1 with uremic encephalopathy, 1 with mitochondrial encephalopathy, 1 with Hashimoto's encephalopathy and 12 with inflammatory diseases of the nervous system.

\section{Neuropathology}

All 45 diagnoses of CJD were neuropathologically confirmed using standard methods [16]. Additionally, prion protein typing was done and polymorphism at codon 129 was determined [25].

Tau Protein, S-100B and 14-3-3 Protein Measurement

Tau protein and S-100B protein were measured with commercially available assays (Innogenetics, Ghent and Byk-Sangtec, Dietzenbach) [20, 26]. Normal levels of tau protein were below $420 \mathrm{pg} / \mathrm{ml}$. The optimal cut-off level for CJD patients was above $1,300 \mathrm{pg} / \mathrm{ml}$ [2]. In a control group, S-100B levels were below $2.2 \mathrm{ng} / \mathrm{ml}$ and above $4.2 \mathrm{ng} / \mathrm{ml}$ in the CJD patients [7]. The 14-3-3 immunoblot was performed on all samples according to the previously published standard method [8].

\section{Statistical Analysis}

The comparison of the tau level and S-100B level between subgroups of the study population was based on nonparametric tests (the Wilcoxon-Mann-Whitney U test for independent comparisons and the Wilcoxon signed-rank test for dependent comparisons).

\section{Marker Difference to Time Difference Ratio}

As we aimed to investigate the dynamics of tau protein and S$100 \mathrm{~B}$ in the follow-up we calculated a marker difference to time difference ratio (MTR): e.g. (level of tau protein at lumbar puncture (LP) 1) - (level of tau protein at LP 2)/(time difference of LP in days).

\section{Results}

Follow-up data were available for 45 patients with neuropathologically confirmed CJD and 45 patients with OND. Patient characteristics (gender, age) are given in table 1. Times between LPs ranged between 2 and 546 days (median: 31 days) in the CJD group and between 1 and 1,252 days (median: $33 ; \mathrm{p}=0.9$ ).

Comparison of Tau Protein Levels in CJD and OND

We analyzed 45 patients with CJD. Twenty-six patients were classified as 'probable' CJD, 9 as 'possible' and 4 were initially classified as 'other' cases. Six patients suffered from genetic CJD. Median tau protein level at the first LP was $2,757 \mathrm{pg} / \mathrm{ml}$ (range $75-21,964 \mathrm{pg} / \mathrm{ml}$ ) and $3,443 \mathrm{pg} / \mathrm{ml}$ (range $75-32,795 \mathrm{pg} / \mathrm{ml}$ ) at the second LP 


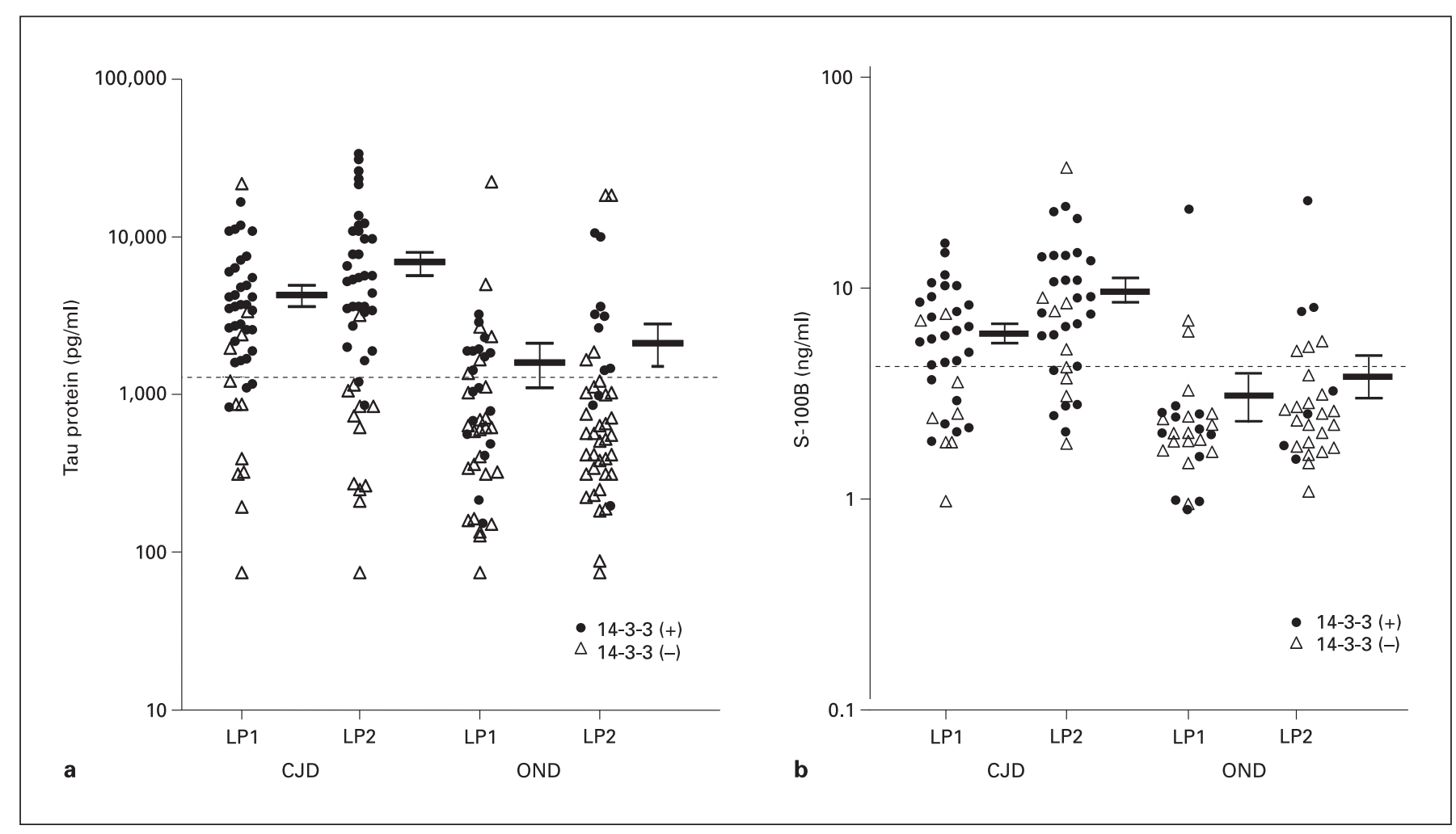

Fig. 1. Tau protein (a) and S-100B (b) levels (both at logarithmic scale) at first and second LP. Dashed lines represent cut-off levels for tau protein $(1,300 \mathrm{pg} / \mathrm{ml})$ and $\mathrm{S}-100 \mathrm{~B}(4.2 \mathrm{ng} / \mathrm{ml})$. Individual values and means $\pm \mathrm{SEM}$ (thick horizontal and vertical lines).

(fig. 1a). Tau protein levels were significantly higher at the second LP $(p=0.003)$. Thirty-four cases $(75 \%)$ had levels above the previously established cut-off level for the diagnosis of CJD $(>1,300 \mathrm{pg} / \mathrm{ml})$ in the first CSF sample. Tau protein rose in 29 cases at the second LP (64\%). Tau protein levels rose especially in 7 cases among the 11 patients who had tau protein levels below $1,300 \mathrm{pg} / \mathrm{ml}$ in the first LP. Four of these rose above the cut-off level and 2 came close to the established cut-off level (1,157 and 1,172 pg/ $\mathrm{ml})$.

The clinical presentation of a CJD patient strongly depends on the PrP type and the polymorphism of codon 129. Typing of the 39 definite sporadic cases according to Parchi [25] was available on 22 cases. The distribution of the polymorphism at codon 129 and prion protein type was as follows: methionine/methionine $\operatorname{PrP}^{\mathrm{Sc}}$ type 1: 9 cases; methionine/methionine $\mathrm{PrP}^{\mathrm{Sc}}$ type 2: 1 case; methionine/valine $\mathrm{PrP}^{\mathrm{Sc}}$ type 1: 2 cases; methionine/valine $\operatorname{Pr}^{\mathrm{Sc}}$ type 2: 4 cases; valine/valine $\operatorname{PrP}^{\mathrm{Sc}}$ type 1: 1 case; valine/ valine $\mathrm{PrP}^{\mathrm{Sc}}$ type $2: 5$ cases. There were no relevant differ- ences of tau protein follow-up measurement within these subgroups.

Four of the 45 CJD (9\%) patients were initially clinically diagnosed with other diseases. Tau protein was above the cut-off level for CJD in 3 patients and even rose in 2 patients. One patient had low levels of tau protein at both LPs. This patient had a valine/valine polymorphism at codon 129.

Genetic CJD: In 3 patients a fatal familial insomnia (FFI) was diagnosed: 2 patients had an insert mutation and 1 patient an E200K mutation of the prion protein gene. S-100B levels rose markedly in all genetic patients. Tau protein levels rose in 3 patients, but stayed below the cut-off levels in 2 (both FFI cases).

Forty-four of forty-five patients with OND were analyzed. The tau protein levels reached a median value of $702 \mathrm{pg} / \mathrm{ml}$ (range $75-22,218 \mathrm{pg} / \mathrm{ml}$ ) in the first LP and $650 \mathrm{pg} / \mathrm{ml}$ (median; range 75-18,285 pg/ml) in the second LP. There was no significant difference between the first and second LP $(p=0.53)$. Sixteen patients $(36 \%)$ were 
Fig. 2. Differences of tau protein (a) and S$100 \mathrm{~B}$ protein $(\mathbf{b})$ in relation to the follow-up time point expressed as MTR.

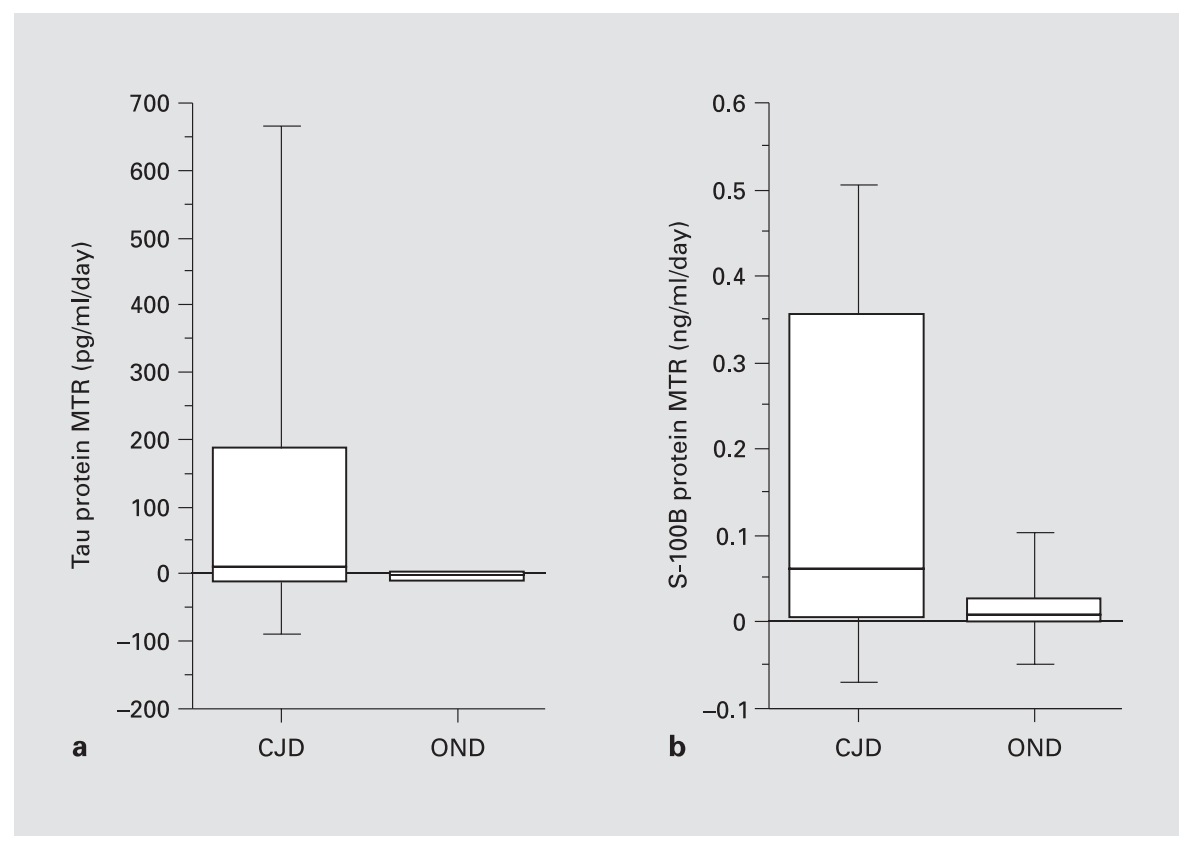

above the cut-off level in the first LP and $12(27 \%)$ in the second LP. In 4 of these 16 patients, tau protein levels decreased below the cut-off level for CJD.

\section{Comparison of MTR in CJD and OND}

MTRs between the CJD and OND group were significantly different, with higher values in the CJD group $(\mathrm{p}<0.05)$ (fig. 2a). The median MTR of CJD between both LPs was $9 \mathrm{pg} / \mathrm{ml} /$ day (range $-1,425$ and 9,214 pg/ $\mathrm{ml} /$ day). The mean MTR for the OND group was $-1 \mathrm{pg} /$ $\mathrm{ml} /$ day (range: -388.9 and $164.6 \mathrm{pg} / \mathrm{ml} /$ day). Patients with multiple infarct syndromes had a positive/increasing gradient (median $292 \mathrm{pg} / \mathrm{ml} /$ day). Patients with AD (MTR: median -1.9 pg/ml/day), frontotemporal dementia (MTR: median $-1.7 \mathrm{pg} / \mathrm{ml} /$ day) and corticobasal degeneration (MTR: median $-2 \mathrm{pg} / \mathrm{ml} /$ day) had decreasing tau levels which is represented by a negative MTR. Furthermore patients with neoplasias of the brain had decreasing MRTs (median $-6 \mathrm{pg} / \mathrm{ml} /$ day).

\section{Comparison of $S-100 B$ Levels in CJD and OND}

We analyzed 31 patients with CJD (18 patients classified as probable, 7 as possible CJD, 3 as other disease, 6 as genetic CJD). All diagnoses of CJD were neuropathologically confirmed. S-100B levels ranged between 1 and $19 \mathrm{ng} / \mathrm{ml}$ in the first LP (median: $5.3 \mathrm{ng} / \mathrm{ml}$ ) and between 1.9 and $37.8 \mathrm{ng} / \mathrm{ml}$ (median: $7.8 \mathrm{ng} / \mathrm{ml}$ ) in the second LP.
S-100B levels were significantly higher at the second LP $(p=0.0007)$ (fig. 1b).

In $21(68 \%)$ of these 31 patients, S-100B protein was above the cut-off level for CJD $(4.2 \mathrm{ng} / \mathrm{ml})$ and in 10 (32\%) below the cut-off level. In the second LP , S-100B increased in 27 cases. Among the 10 patients with S-100B protein levels below $4.2 \mathrm{ng} / \mathrm{ml}$, the S-100B protein levels of 9 patients had risen in the second LP. In 5 of these patients, they had risen above the cut-off level.

S-100 levels of 3 of the CJD patients with an initial diagnosis of 'other disease' were available. In the first LP of 2 patients, levels below the cut-off level were measured. In all 3 patients, the S-100B level had risen. Two patients then had levels above the cut-off level.

We analyzed the S-100B levels of 28 patients of the OND group. The S-100B levels reached values between 0.9 and $23.8 \mathrm{ng} / \mathrm{ml}$ (median: $2.1 \mathrm{ng} / \mathrm{ml}$ ) in the first sample and levels between 1.1 and $26.1 \mathrm{ng} / \mathrm{ml}$ (median: $2.6 \mathrm{ng} /$ $\mathrm{ml}$ ) in the second sample. Levels of S-100B were significantly higher in the second LP $(\mathrm{p}=0.018)$. Three patients $(11 \%)$ had levels above the cut-off level in the first LP and $6(21 \%)$ in the second LP. The S-100B levels of 1 of these patients decreased to below the cut-off levels for CJD.

Follow-Up Investigation of S-100B in CJD and OND

The MTRs between CJD and OND group for S-100B were significantly different $(p<0.02)($ fig. $2 b)$ with higher 
values in the CJD group. The MTRs of the CJD group ranged between -0.93 and $3.21 \mathrm{ng} / \mathrm{ml} /$ day (median: 0.06 $\mathrm{ng} / \mathrm{ml} /$ day), whereas in the OND group they ranged between -0.33 and $0.23 \mathrm{ng} / \mathrm{ml} /$ day (median: $0.01 \mathrm{ng} / \mathrm{ml} /$ day).

Slightly increasing levels of S-100B were observed in $\mathrm{AD}$ (MTR, median $0.016 \mathrm{ng} / \mathrm{ml} /$ day), corticobasal degeneration (MTR, median $0.01 \mathrm{ng} / \mathrm{ml} /$ day), infectious diseases (MTR, median: $0.019 \mathrm{ng} / \mathrm{ml} /$ day), hepatic encephalopathy (MTR, median: $0.02 \mathrm{ng} / \mathrm{ml} /$ day).

\section{Detailed Description of the OND Group}

\section{Alzheimer's Disease}

The diagnoses of 3 out of the 8 patients with $\mathrm{AD}$ were neuropathologically confirmed. In 2 patients (25\%), the levels of tau protein were above the cut-off level in the first LP. In 1 out of 6 patients with AD the S-100B-level was above the cut-off level in the first LP. In the second LP of this patient the S-100B level even increased, while the tau protein level remained stable. In the second LP of 2 of the other 5 patients S-100B rose above the cut-off level for CJD, whereas the level of tau protein remained stable and was within the typical range for AD. 14-3-3 assay was positive in 3 samples of the first LP.

\section{Corticobasal Ganglionic Degeneration}

We investigated 4 patients with CBD. In all samples the levels of tau protein and S-100B protein were below the cut-off level for CJD. In 1 patient tau protein rose in the second LP $(778-1,130 \mathrm{pg} / \mathrm{ml})$. In 3 patients the S100B level rose without reaching the cut-off level for CJD. In 1 patient the 14-3-3 assay was positive in the first LP (tau protein $483 \mathrm{pg} / \mathrm{ml}, \mathrm{S}-100 \mathrm{~B} 2.15 \mathrm{ng} / \mathrm{ml}$ ).

\section{Vascular Dementia}

In the CSF of 2 out of 4 patients the tau protein was above the cut-off level and increased in the follow-up investigation. In 1 of the 2 patients S-100B rose from $2.6 \mathrm{ng} / \mathrm{ml}$ above the cut-off level to $8.1 \mathrm{ng} / \mathrm{ml}$ (tau protein 1,849 to $10,368 \mathrm{pg} / \mathrm{ml}$ ). A decline was observed in only 1 case. The period of time between these LPs ranged from 8 to 53 days. With one exception 14-3-3 assay was positive in all CSF samples.

\section{Frontotemporal Dementia}

Two patients with FTD were investigated. Tau protein levels of these patients were within the normal range in the first and second LP. S-100B levels were below the cutoff level for CJD. In neither of these samples 14-3-3 proteins were detected.
Miscellaneous Neurodegenerative Disease

Only 1 patient with LBD was investigated in the follow-up. Tau protein and S-100B protein in both LPs were in the normal range, whereas 14-3-3 assay was positive in the first sample.

The patient with progressive subcortical gliosis (Neumann's disease) presented with a tau protein level above the cut-off level in the first and in the follow-up investigation $(3,160$ and $2,621 \mathrm{pg} / \mathrm{ml})$ after 26 days. S-100B-levels remained within the normal range.14-3-3 assay was always positive.

The levels for tau protein and S-100B were within the normal range for the patient suffering from motor neuron disease and the patient with mitochondrial encephalopathy.

Inflammation of the Central Nervous System and

Hashimoto's Encephalopathy

Seven patients with an acute inflammation of the CNS and 5 patients with a chronic inflammation of the CNS were analyzed. Tau protein was above the cut-off level in 3 out of 7 patients with acute inflammations and in 2 out of 5 with chronic inflammation in the first LP. Tau levels declined in only 2 patients (from 2,336 to $1,651 \mathrm{pg} / \mathrm{ml}$ and from 22,218 to $3,549 \mathrm{pg} / \mathrm{ml}$ ). S-100B increased in 5 out of 6 available patients. In almost all samples the 143-3 assay was positive.

The patient with Hashimoto's encephalopathy had normal levels of tau protein. S-100B levels rose from normal to $5.1 \mathrm{ng} / \mathrm{ml}$ after 423 days.

\section{Hepatic Encephalopathy and Uremic}

Encephalopathy

We analyzed 3 patients with hepatic encephalopathy caused by liver cirrhosis. Two patients had levels above the cut-off level for CJD. In 1 patients the tau protein level dropped from 2,825 to $750 \mathrm{pg} / \mathrm{ml}$ within 70 days. In this patient 14-3-3 proteins were detected in both LPs. The other patient with elevated levels had constantly high levels $(1,662-1,416 \mathrm{pg} / \mathrm{ml})$. Levels of S-100B were not elevated (values only for 1 patient). The patient with uremic encephalopathy exhibited with very high and increasing tau protein levels and a positive 14-3-3 immunoblot. S-100B protein stayed within the normal range.

\section{Epilepsy}

Two patients suffering from epilepsy were investigated for tau protein. In one sample tau protein was initially above the cut-off level and dropped below in the followup investigation. In both samples 14-3-3 assay was nega- 
tive. In the other patient tau protein levels rose from 604 to $3,088 \mathrm{pg} / \mathrm{ml}$ within 15 days and dropped again to $136 \mathrm{pg} / \mathrm{ml}$ after again 115 days. In all of these samples 14-3-3 assay was positive. None of these samples were investigated for S-100B.

\section{Neoplasia}

We analyzed the CSF of 2 patients with neoplastic diseases. One case showed an elevated tau protein level with nearly unchanged values (1,380 and $1,433 \mathrm{pg} / \mathrm{ml})$. S-100B level in this patient was only slightly elevated and dropped in the second LP. 14-3-3 assay was negative in both samples. The second patient had increased levels of tau protein $(1,843 \mathrm{pg} / \mathrm{ml})$ and a positive $14-3-3$ assay, whereas the S-100B level was in the normal range. In the followup investigation tau protein decreased to $345 \mathrm{pg} / \mathrm{ml}$ and 14-3-3 assay was negative.

\section{Depression}

All markers were within the normal range in both patients.

\section{Discussion}

Measurement of tau protein and S-100B has a high diagnostic impact in the differential diagnosis of CJD. Sensitivities and specificities of about $90 \%$ were reached $[2,4-7]$. In the vast majority of studies nondemented control patients have tau protein levels below $420 \mathrm{pg} / \mathrm{ml}$. Patients with neurodegenerative disease such as AD have levels between 420 and $800 \mathrm{pg} / \mathrm{ml}$, whereas patients with CJD have levels above $1,300 \mathrm{pg} / \mathrm{ml}$. The situation for the astroglial marker $\mathrm{S}-100 \mathrm{~B}$ is quite similar although not as many studies for this protein have been published [22] Nondemented patients have levels below $2.2 \mathrm{ng} / \mathrm{ml}$, some patients with other neurodegenerative diseases have elevated levels and patients with CJD have S-100B levels above $4.2 \mathrm{ng} / \mathrm{ml}$. In some cases the clinical diagnosis of CJD was challenged and a second LP was done. We analyzed all CSF samples of patients with a differential diagnosis of CJD and from whom more than one sample was available. CSF was sampled over the last 5 years in our counseling laboratory for CJD. During that time nearly 2,500 samples were analyzed for patients with a differential diagnosis of CJD but repeat samples were available only for 90 patients (45 CJD, 45 OND).

As the time of the second LP is determined by the treating physician, time intervals varied between 1 and 1,252 days. In an independent comparison we could show that for the individual CJD patients a significant rise of tau protein and S-100B protein occurred. For the OND group only a just significant increase of S-100B was observed, whereas tau protein was not significantly different. The MTR clarifies this observation.

From our investigation we conclude that patients with CJD have mainly increasing levels of S-100B and tau protein in the follow-up investigation. The S-100B increase might represent an ongoing astroglial activation and possible destruction, whereas the increase of tau protein might represent ongoing neuronal loss. In an anecdotal observation of 3 CJD cases a decrease of S-100B was described at later stages [27]. This was only rarely observed in our group. Nor were decreasing levels of tau protein often observed. At very advanced stages of CJD the levels may still decrease; however this was not observed in our study.

We further conclude that in other neurodegenerative diseases S-100B and tau protein remain mainly stable or show only a mild increase. This finding might be due to the much slower time course of these diseases. In inflammatory diseases S-100B and tau protein levels might even rise as in CJD. However, these diseases are usually easier to exclude by other clinical findings than neurodegenerative diseases like AD.

Since only immunoblot was available for 14-3-3 protein measurements, a comparison of levels is hardly possible and is only of limited use for the follow-up. We suppose that repetitive analysis of this marker at well-defined times might be useful to monitor disease progression to investigate possible therapeutic effects in a group comparison. However, as demonstrated by our analysis, it will not be possible to predict the progression for an individual case as follow-up investigations vary from one patient to patient.

The challenge for the diagnosis of CJD is the early and differential diagnosis and it seems that repetitive LPs provide a better differential diagnosis. It will have to be elucidated whether the measurement of additional markers such as phospho-tau or the amyloid beta-peptide pattern will yield even better results [5, 28, 29].

\section{Acknowledgement}

The authors thank the physicians who provided data on suspect cases to the German CJD counseling laboratory. This study was supported in part by a grant from the Federal Ministry of Health and social security (BMGS), Federal Ministry of Science and Technology (BMBF) and the Deutsche Forschungsgemeinschaft (Center for molecular physiology of the brain). 


\section{References}

1 Steinhoff BJ, Racker S, Herrendorf G, et al: Accuracy and reliability of periodic sharp wave complexes in Creutzfeldt-Jakob disease. Arch Neurol 1996;53:162-166.

2 Otto M, Wiltfang J, Cepek L, et al: Tau protein and 14-3-3 protein in the differential diagnosis of Creutzfeldt-Jakob disease. Neurology 2002; 58:192-197.

3 Otto M, Wiltfang J, Tumani H, et al: Elevated levels of tau-protein in cerebrospinal fluid of patients with Creutzfeldt-Jakob disease. Neurosci Lett 1997;225:210-212.

4 Kapaki E, Kilidireas K, Paraskevas GP, Michalopoulou M, Patsouris E: Highly increased CSF tau protein and decreased beta-amyloid (1-42) in sporadic CJD: A discrimination from Alzheimer's disease? J Neurol Neurosurg Psychiatry 2001;71:401-403.

5 Van Everbroeck B, Quoilin S, Boons J, Martin JJ, Cras P: A prospective study of CSF markers in 250 patients with possible Creutzfeldt-Jakob disease. J Neurol Neurosurg Psychiatry 2003;74:1210-1214.

6 Beaudry P, Cohen P, Brandel JP, et al: 14-3-3 protein, neuron-specific enolase, and S-100 protein in cerebrospinal fluid of patients with Creutzfeldt-Jakob disease. Dement Geriatr Cogn Disord 1999;10:40-46.

7 Otto M, Stein H, Szudra A, et al: S-100 protein concentration in the cerebrospinal fluid of patients with Creutzfeldt-Jakob disease. J Neurol 1997;244:566-570.

8 Hsich G, Kenney K, Gibbs CJ, Lee KH, Harrington MG: The 14-3-3 brain protein in cerebrospinal fluid as a marker for transmissible spongiform encephalopathies. N Engl J Med 1996;335:924-930.

9 Kenney K, Brechtel C, Takahashi H, Kurohara $\mathrm{K}$, Anderson P, Gibbs CJ, Jr: An enzymelinked immunosorbent assay to quantify 14-33 proteins in the cerebrospinal fluid of suspected Creutzfeldt-Jakob disease patients. Ann Neurol 2000;48:395-398.
10 Zerr I, Bodemer M, Gefeller O, et al: Detection of 14-3-3 protein in the cerebrospinal fluid supports the diagnosis of Creutzfeldt-Jakob disease. Ann Neurol 1998;43:32-40.

11 WHO: Consensus on criteria for sporadic CJD Geneva, WHO, 1998. http://www.who.int/ emc-documents/tse/docs/whoemczdi989.pdf.

12 Green AJ, Knight RS, Macleod MA, Lowman A, Will RG: Misleading results with the 14-3-3 assay for the diagnosis of Creutzfeldt-Jakob disease. Neurology 2001;56:986-987.

13 Green AJ, Thompson EJ, Stewart GE, et al: Use of 14-3-3 and other brain-specific proteins in CSF in the diagnosis of variant CreutzfeldtJakob disease. J Neurol Neurosurg Psychiatry 2001;70:744-748.

14 Aksamit AJ: Cerebrospinal fluid 14-3-3 protein: Variability of sporadic Creutzfeldt-Jakob disease, laboratory standards, and quantitation. Arch Neurol 2003;60:803-804.

15 Geschwind MD, Martindale J, Miller D, et al: Challenging the clinical utility of the 14-3-3 protein for the diagnosis of sporadic Creutzfeldt-Jakob disease. Arch Neurol 2003;60: 813-816.

16 Kretzschmar HA, Ironside JW, DeArmond SJ, Tateishi J: Diagnostic criteria for sporadic Creutzfeldt-Jakob disease. Arch Neurol 1996; 53:913-920.

17 Bieschke J, Giese A, Schulz-Schaeffer W, et al: Ultrasensitive detection of pathological prion protein aggregates by dual-color scanning for intensely fluorescent targets. Proc Natl Acad Sci USA 2000;97:5468-5473.

18 Hill AF, Butterworth RJ, Joiner S, et al: Investigation of variant Creutzfeldt-Jakob disease and other human prion diseases with tonsil biopsy samples. Lancet 1999;353:183-189.

19 Galasko D, Chang L, Motter R, et al: High cerebrospinal fluid tau and low amyloid beta42 levels in the clinical diagnosis of Alzheimer disease and relation to apolipoprotein E genotype. Arch Neurol 1998;55:937-945.
20 Hulstaert F, Blennow K, Ivanoiu A, et al: Improved discrimination of $\mathrm{AD}$ patients using beta-amyloid(1-42) and tau levels in CSF. Neurology 1999;52:1555-1562.

21 Frank RA, Galasko D, Hampel H, et al: Biological markers for therapeutic trials in Alzheimer's disease. Proceedings of the biological markers working group; NIA initiative on neuroimaging in Alzheimer's disease. Neurobiol Aging 2003;24:521-536.

22 Verbeek MM, De Jong D, Kremer HP: Brainspecific proteins in cerebrospinal fluid for the diagnosis of neurodegenerative diseases. Ann Clin Biochem 2003;40:25-40.

23 Masters CL, Harris JO, Gajdusek DC, Gibbs CJJ, Bernoulli C, Asher DM: Creutzfeldt-Jakob disease: Patterns of worldwide occurrence and the significance of familial and sporadic clustering. Ann Neurol 1979;5:177-188.

24 Will RG: Epidemiology of Creutzfeldt-Jakob disease. Br Med Bull 1993;49:960-970.

25 Parchi P, Castellani R, Capellari S, et al: Molecular basis of phenotypic variability in sporadic Creutzfeldt-Jakob disease. Ann Neurol 1996;39:767-778.

26 Otto M, Wiltfang J, Schütz E, et al: Diagnosis of Creutzfeldt-Jakob disease by measurement of S100 protein in serum: Prospective casecontrol study. BMJ 1998;316:577-582.

27 Jimi T, Wakayama Y, Shibuya S, et al: High levels of nervous system-specific proteins in cerebrospinal fluid in patients with early stage Creutzfeldt-Jakob disease. Clin Chim Acta 1992;211:37-46.

28 Van Everbroeck B, Green A, Vanmechelen E, et al: Phosphorylated tau in cerebrospinal fluid as a marker for Creutzfeldt-Jakob disease. J Neurol Neurosurg Psychiatry 2002;73:79-81.

29 Wiltfang J, Esselmann H, Smirnov A, et al: Beta-amyloid peptides in cerebrospinal fluid of patients with Creutzfeldt-Jakob disease. Ann Neurol 2003;54:263-267. 